\title{
PELAPISAN CABE MERAH DENGAN NANOPARTIKEL KITOSAN UNTUK MENGHAMBAT KEHILANGAN VITAMIN C DAN SUSUT BOBOT
}

\author{
Riskiono Slamet
}

Jurusan Kimia, Fakultas Matematika dan Ilmu Pengetahuan Alam, Universitas Negeri Jakarta, Rawamangun 13220, Jakarta

*Corresponding author:

\begin{abstract}
Abstrak
Penelitian ini bertujuan untuk menentukan pengaruh konsentrasi nanopartikel kitosan yang terhadap kandungan vitamin $\mathrm{C}$ dan susut bobot cabe merah. Cabe merah dilapis dengan larutan nanopartikel kitosan, disimpan pada suhu $20^{\circ} \mathrm{C}$, dan kandungan vitamin $\mathrm{C}$ serta susur bobot diukur setiap 4 hari sekali selama 16 hari. Hasil penelitian menunjukkan bahwa cabe merah yang dilapis dengan larutan yang mengandung nanopartikel kitosan 3\%, kehilangan vitamin C sebesar 30\% pada hari ke 12, sementara cabe merah yang tidak dilapis, kehilangan vitamin C sebesar 53,8\%. Sementara kehilangan susut bobot juga menunjukkan pola yang sama dengan vitamin $\mathrm{C}$. Hasil terbaik diperoleh jika cabe merah dilapis dengan larutan yang mengandung 3\% nanopartikel kitosan.
\end{abstract}

Kata Kunci:

\section{Abstract}

In this research the possible use of chitosan nanoparticle coating on green peppers (Capsium annuum L) after harvesting and to determined the effect of chitosan nanoparticle coating formulation to control the barrier properties toward water and oxygen.was investigated. Manually green peppers were treated with a solution of $1 \%, 2 \%$ and $3 \%$ nanoparticle chitosan and then stored at $20^{\circ} \mathrm{C}$. The parameters of physcochemical properties such as weight loss and ascorbic acid concentrations, were monitored during storage 4 days until 16 days. Results indicated that the physicochemical properties of weight loss and ascorbic concentration did not show remarkable change during storage period. and the longest storage life 16 The best quality of greeen peppers days were obtained from the chitosan nanoparticle coating at 3\% concentration. The results suggest that the biodegradable coating with higher water vapour permeability can be used to maintain the quality and sanitary conditions of freshly harvested green peppers in modified atmosphere packaging.

Keywords :chitosan nanoparticle, green pepper, vitamin C, total weight

\section{Pendahuluan}

Buah-buahan termasuk produk pertanian yang mudah rusak, serta kualitasnya cepat menurun setelah pasca panen dan selama di perjalanan. Cabe merah merupakan salah satu jenis buah yang mudah rusak. Kerusakan buah cabe merah terutama disebabkan karena kehilangan lapisan lilin alami, sehingga laju transpirasi uap air meningkat, mengakibatkan pelunakan pada jaringan buah, buah menjadi layu, busuk, keriput dan lunak [1].

Proses metabolik yang terpenting sesudah panen adalah respirasi yang meliputi perombakan substansi organis, proses pemecahan secara oksidasi pada senyawa kompleks dan senyawa organik yang terdapat dalam sel seperti zat pati, asam-asam organik dan lain-lain, menjadi molekul- molekul yang sederhana seperti $\mathrm{CO}_{2}$, dan $\mathrm{H}_{2} \mathrm{O}$ dan energi.

Salah satu cara untuk memperlambat laju respirasi adalah dengan pelapisan dari bahan pelapis yang aman dimakan.Lerdthanangkul dan Krochta[2] melaporkan bahwa cabe merah yang dilapisi dengan lemak mampu mempertahankan kesegaran dan kekerasan cabe merah selama 20 hari pada suhu $10^{\circ} \mathrm{C} .3$ Shimon Meir et al [3] menggunakan methyl jasmonat sebagai pelapis untuk mencegah chilling injuri pada cabe merah. Pada penelitiannya mengenai pengaruh suhu dan lama perendaman, Falik et al [4] melaporkan bahwa cabe merah yang direndam pada suhu $50^{\circ} \mathrm{C}$ selama 3 menit tahan terhadap jamur Botrytis cinerea dan Alternaria Alternata. Maalekuu et al [5] mempelajari pengaruh 
penyimpanan cabe merah pada suhu $8^{0} \mathrm{C}$ terhadap aktifitas enzym (galaktanase, glikosidase, glukanase, mannanase, xylanase), perubahan fraksi karbohidrat (glikosa, galaktosa, mannosa, xylosa, arabonosa) dan perubahan tekstur. Hasil penelitiannya menunjukkan bahwa cabe merah yang disimpan pada suhu $8^{0} \mathrm{C}$ selama 5 hari kehilangan karbohidrat sebesar 40\% dan kehilangan tekstur 0.34. Menurut Yage Xing [6] kehilangan air lebih dari 5\% mengakibatkan cabe merah menjadi layu dan keriput. Erol dan Sibel [7] menggunakan metil selulosa dan polietilen glikol sebagai bahan dasar pelapis cabe merah Untuk meningkatkan sifat barrier ditambahkan berbagai additif seperti asam stearat, asam sitrat dan asam askorbat. Hasil penelitiannya menunjukkan bahawa pelapis dengan komposisi metilselulosa-polietilen glikol asam stearat sangat efektif untuk mencegah kehilangan uap air dan vitamin $\mathrm{C}$ pada cabe merah dan alpokat selama 12 hari.

Salah satu senyawa polisakarida yang sekarang banyak digunakan sebagai bahan pelapis baik sebagai edible coating maupun edible film adalah kitosan. Kitosan polimer alam yang tidak toksik, aman dimakan, biodegradable, biocompatibility, telah dipelajari untuk diaplikasikan secara komersial dalam biomedikal, makanan, dan industri kimia sebagai adsorben, edible coating maupun edible film serta sebagai senyawa antibakteri [8-9]. Kitosan merupakan bahan yang baik untuk membuat lapisan antimikroba berdasarkan sifat pembentuk lapisannya [10] Kitosan dapat membentuk lapisan semipermiabel sehingga mampu memodifikasi lingkungan di dalam jaringan buah, dengan demikian pematangan tertunda dan laju transpirasi menurun. Kitosan, seperti bahan pelapis dari karbohidrat lainnya, memiliki sifat selektif terhadap gas oksigen dan karbon dioksida, tetapi kurang mampu menghambat perpindahan air. Secara umum pelapis yang tersusun dari polisakarida dan turunannya hanya sedikit menahan penguapan air tetapi efektif untuk mengontrol difusi dari berbagai gas[11].

Kitosan memiliki kemampuan bioaktif sebagai penghambat pertumbuhan kapang dan jamur. Polikation alami kitosan dapat menghambat pertumbuhan kapang dan jamur yang patogen, di antaranya jamur tanah seperti Fusarium Oxyspra, dan Rhizoetonia solani. Kitosan mempengaruhi berbagai proses biologis dalam jaringan tanaman dengan mengaktifkan enzim kitinase yang dimilikinya, membantu jaringan tanaman dalam melawan jamur dengan interaksi antimikroba secara langsung maupun mengaktifkan pertahanan alami dari tanaman tersebut. Kitosan juga mampu menghambat germinasi spora dan pertumbuhan kapang Bottyris cinerea dan Rhizopus stolonifer[12].

Larutan kitosan dalam keadaan kering mempunyai kemampuan untuk menahan laju transpirasi dan laju transmisi karena dapat membentuk jaringan kristal. Larutan pelapis kitosan telah digunakan untuk melapisi permukaan buah jeruk buah [13], Li Chi[14], buah jujuba [15], buah china [16]), lengkeng[17], daging panggang [18] daging setengah matang [19].

Untuk meningkatkan sifat mekanik dan sifat serta sifat permeabilitasnya terhadap uap air, kitosan direkayasa menjadi nanopartikel kitosan dengan merubah strukturnya yang bersifat kristalin menjadi amorph melalui rekayasa ikatan silang gugus amina $\left(-\mathrm{NH}_{2}{ }^{+}\right)$ dari kitosan dengan gugus hidrogen phosphat $\left(-\mathrm{HPO}_{4}{ }^{-2}\right)$ dari Sodium Tripoli Phosphatt (STPP). Reaksi ikatan silang antara kitosan dengan STPP ditunjukkan pada gambar 1 .

\section{Metodologi Penelitian}

\subsection{Alat dan Bahan}

Neraca analitik, pHmeter, hot plate, magnetic strirer, freezer, sentrifuse,buret, statif dan klep, gelas kimia, spatula, pengaduk kaca, plat kaca, bak plastik, oven.

Kitosan, asam asetat, gliserol, tween 80 , natrium hidroksida, sodium tripoliphosphat, akuadest, cabe merah.

\subsection{Prosedur Kerja}

\section{Pembuatan Nanopartikel Kitosan}

Sebanyak $3 \mathrm{~g}$ kitosan dilarutkan ke dalam $100 \mathrm{~mL}$ larutan asam asetat $0,5 \%(\mathrm{v} / \mathrm{v})$ dalam 
gelas kimia $1000 \mathrm{~mL}$, dan didiamkan selama 24 jam. Kemudian larutan kitosan di-stirrer menggunakan magnetic stirrer dengan kecepatan $1650 \mathrm{rpm} /$ menit selama 20 menit pada suhu kamar, sambil menambahkan 98,5 $\mathrm{mL}$ larutan sodium tripoliphosphat $0,145 \%(\mathrm{w} / \mathrm{v})$ secara perlahan $(10,0 \mathrm{~mL} / \mathrm{menit})$ menggunakan buret. Larutan yang dihasilkan kemudian disimpan dalam freezer pada suhu sekitar $-4^{\circ} \mathrm{C}$ selama 24 jam. Setelah itu, dikeluarkan dari freezer dan ditempatkan pada suhu kamar hingga mencair, lalu di-stirrer dengan kecepatan $1650 \mathrm{rpm} /$ menit selama 24 jam. Selama proses berlangsung, gelas kimia ditutup dengan aluminium foil. Selanjutnya larutan disentrifuse selama 1 jam. Endapan yang terbentuk kemudian dipisahkan, dikeringanginkan pada suhu kamar selama dua hari. Kemudian endapan dihaluskan dengan alu hingga berbentuk serbuk yang sangat halus menyerupai abu. Selanjutnya serbuk nanopartikel kitosan tersebut disimpan dalam botol, lalu ditutup rapat.Karakterisasi nanopartikel kitosan diukur menggunakan FTIR, XRD dan TEM.

\section{Pelapisan Cabe Merah Dengan Larutan Nanopartikel Kitosan}

Cabe merah yang dibeli dari pasar, dipilih berdasarkan ukuran dan penampakan. Celupkan cabe merah ke dalam larutan nanopartikel kitosan selama 30 detik. Angkat dan tiriskan. Letak cabe merah pada bak plastik yang telah diberi label, kemudian simpan pada suhu kamar, lakukan uji kualitas cabe merah pada hari ke 0, 4,8 dan 12 hari.

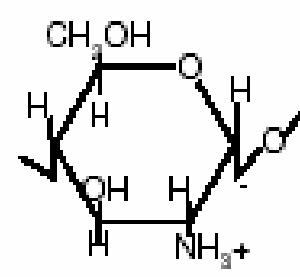
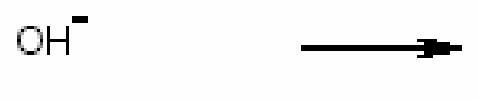

Deprotonation
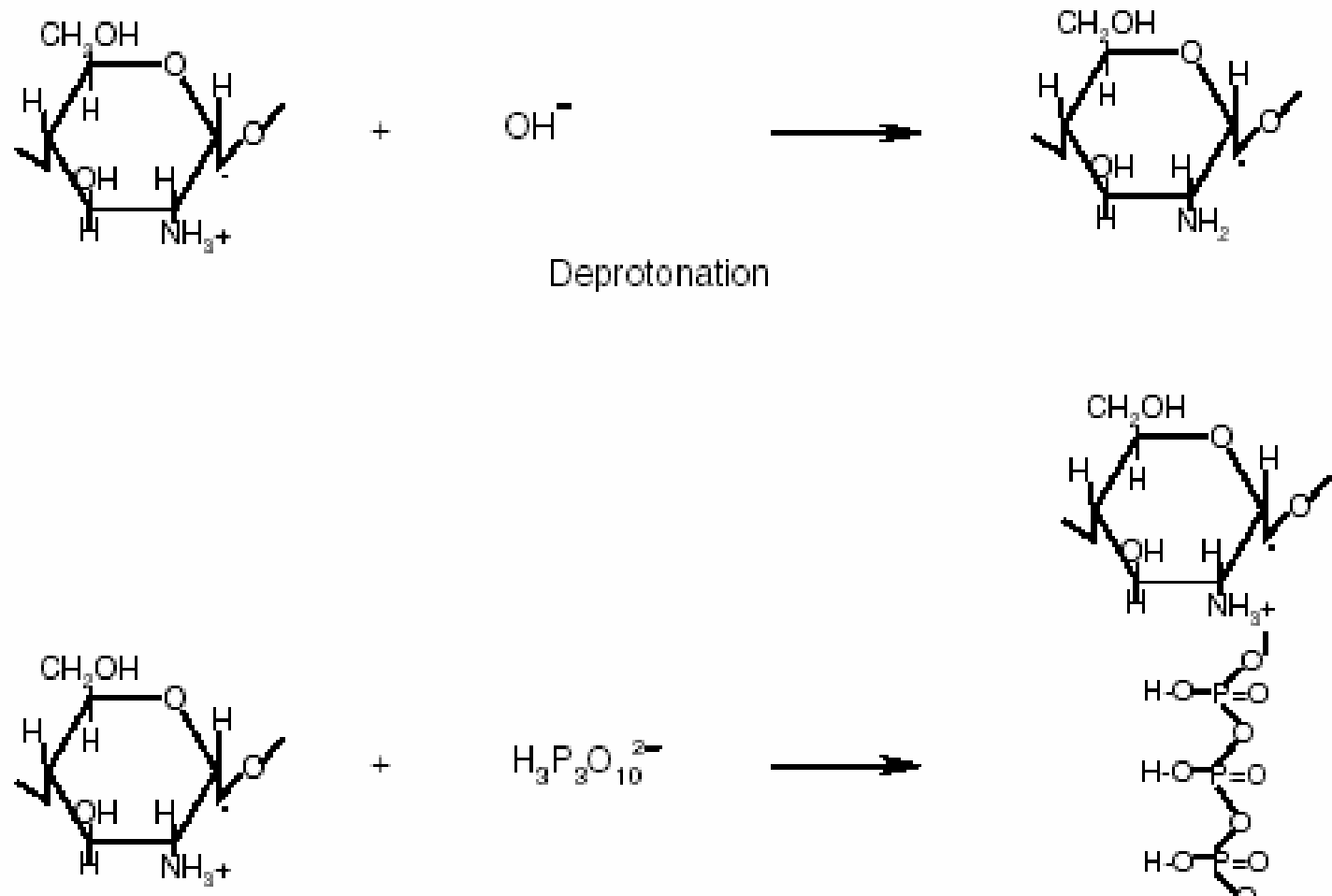

ionic crosslinking
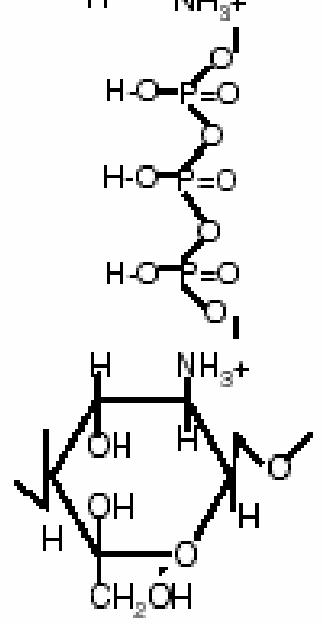

Gambar 1. Proses Reaksi Ikatan Silang Pada Pembuatan Nanopartikel Kitosan 


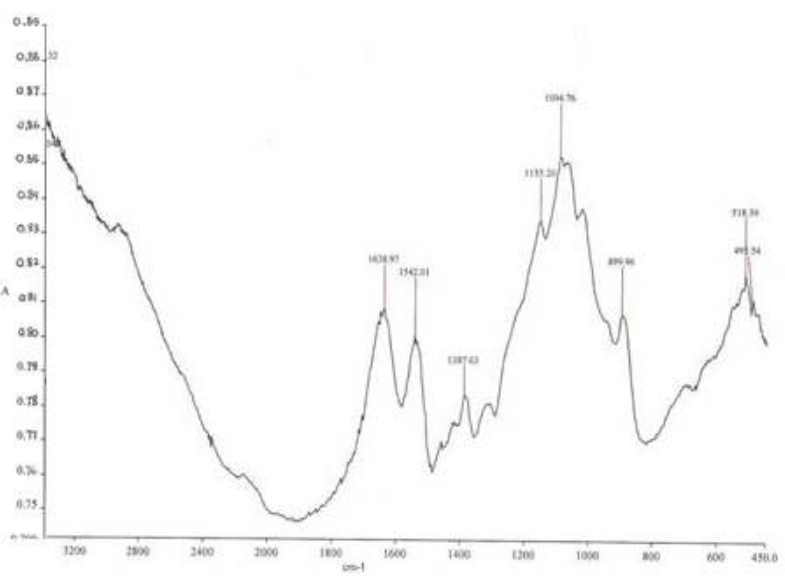

Gambar 2. Spektra FTIR Nanopartikel Kitosan

Uji Kualitas Cabe Merah yang Dilapis Dengan Nanopartikel Kitosan

\section{Uji Susut Bobot}

Cabe merah yang telah dilapis, disimpan dalam desikator. Kemudian timbang beratnya setiap dua hari sekali. Pengukuran susut bobot dihitungt berdasarkan perbedaan berat mulamula dengan berat pada saat diukur. Persentase susut bobot dihitung berdasarkan persamaan

Berat awal - berat akhir

$\%$ susut bobot $=$

Berat mula-mula

\section{Uji Vitamin C}

Kadar vitamin $\mathrm{C}$ ditentulan secara titrasi. Untuk itu 10 gram cabe merah yang telah dihaluskan, dilarutkan dengan $100 \mathrm{ml}$ akuadest, kemudian pindahkan ke dalam labu ukur $250 \mathrm{ml}$ dan diencerkan dengan akuadest sampai tanda batas. Labu ukur dibolak balik sampai homogen. Ambil 25 larutan ini, masukkan ke dalam erlemeyer, tambahkan 2 mlamylum 1\%, titrasi dengan yodium $0,01 \mathrm{M}$ sampai larutan berwarna biru. Catat volume yodium yang digunakan. Kadar vitamin $\mathrm{C}$ dihitung dengan persamaan

$$
\mathrm{V} \times 0,88 \text { × Fp x } 100
$$

$\operatorname{Vitamin} \mathrm{C}(\mathrm{mg} / \mathrm{ml})=$

\section{G}

$\mathrm{V}=$ volume yodium $(\mathrm{ml})$

$\mathrm{Fp}=$ faktor pengenceran

$\mathrm{G}=$ berat cabe merah

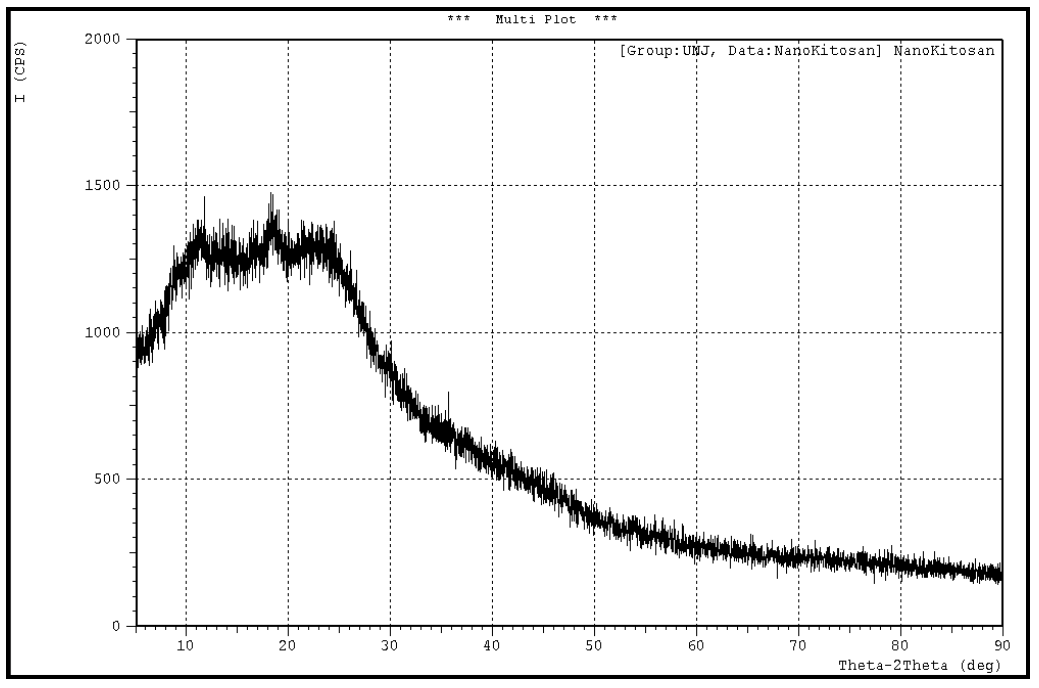

Gambar 3. Pola Difraksi Nanopartikel Kitosan 


\section{Hasil dan Pembahasan}

\subsection{Karakterisasi Nanopartikel Kitosan Fourier Transform Infrared (FTIR)}

Hasil karakterisasi nanopartikel kitosan menggunakan FTIR ditunjukkan pada gambar 2.Data spektra FTIR nanopartikel kitosan pada gambar 2 menunjukkan pita-pita serapan gugus fungsi yang ada pada nanopartikel kitosan. Pita-pita serapan yang khas ditunjukkan pada bilangan gelombang 3435,$68 ; 2884,46 ; 1654,75 ; 1595,13 ; 1378,68$; 1151,99; 1082,97; dan 1033,10 $\mathrm{cm}^{-1}$. Pada bilangan gelombang 3435,68 $\mathrm{cm}^{-1}$ menunjukkan vibrasi regang $\mathrm{O}-\mathrm{H}$ dan $\mathrm{N}-\mathrm{H}$, $2884,46 \mathrm{~cm}^{-1}$ menunjukkan vibrasi regang $\mathrm{C}$ $\mathrm{H}, 1654,75 \mathrm{~cm}^{-1}$ menunjukkan vibrasi $\mathrm{C}=\mathrm{O}$ amida, $1595,13 \mathrm{~cm}^{-1}$ menunjukkan vibrasi regang $\mathrm{N}-\mathrm{H}, 1378,68 \mathrm{~cm}^{-1}$ menunjukkan vibrasi lentur $\mathrm{C}-\mathrm{H}, \quad 1151,99 \mathrm{~cm}^{-1}$ menunjukkan vibrasi regang $\mathrm{P}=\mathrm{O}, 1082,97$ $\mathrm{cm}^{-1}$ menunjukkan adanya rentangan $\mathrm{C}-\mathrm{O}$, dan $1033,10 \mathrm{~cm}^{-1}$ menunjukkan vibrasi lentur $\mathrm{O}$ $\mathrm{H}$.

Adanya serapan pada daerah 1595,13 $\mathrm{cm}^{-1}$ menunjukkan terjadinya penurunan intensitas serapan $\mathrm{N}-\mathrm{H}$ pada nanopartikel kitosan akibat reaksi ikat silang antara gugus amino dan ion tripolifosfat. Selain itu serapan pada daerah 1082,97 $\mathrm{cm}^{-1}$ menunjukkan adanya gugus $\mathrm{P}=\mathrm{O}$ yang terbentuk juga akibat reaksi ikat silang yang terjadi antara gugus amino dan ion tripolifosfat. Kedua serapan ini tidak dimiliki oleh molekul kitosan (gambar 2).

\section{Difraksi Sinar-X}

Karakterisasi nanopartikel kitosan dengan difraksi sinar-X ini menggunakan instrumen Shimadzu XRD 7000 buatan Jepang. Pengukuran dilakukan pada rentang $5,00^{\circ}$ sampai dengan $89,98^{\circ}$ dengan menggunakan $\mathrm{Cu}$ sebagai sumber sinar pada panjang gelombang $(\lambda) \quad 0,154 \mathrm{~nm}$. Pola difraksi nanopartikel kitosan spesifik sangat lebar seperti terlihat pada gambar 3 .

Pola difraksi sinar-X nanopartikel kitosan pada gambar 3 menunjukkan pola difraksi amorf tanpa kristalinitas. Pola difraksi amorf yang sangat lebar pada hasil karakterisasi nanopartikel kitosan telah mengindikasikan bahwa material tersebut memiliki ukuran partikel atau kristalit yang sangat kecil. Hal ini dikarenakan kristalit yang berukuran sangat kecil memiliki bidang pantul yang terbatas.

Lifeng et al.[20] membuktikan adanya perbedaan kristalinitas pada kitosan dan nanopartikel kitosan. Berdasarkan penelitiannya kitosan memiliki puncak yang kuat pada $2 \theta$ di daerah $10,4^{0}$ dan $21,8^{0}$ yang mengindikasikan tingginya derajat kristalinitas kitosan. Sedangkan pada nanopartikel kitosan kedua puncak ini tidak ditemukan. Hal ini menunjukkan bahwa kristalinitas kitosan berkurang setelah terjadinya proses ikat silang. Proses ikat silang menyebabkan jarak antara partikel dalam nanopartikel kitosan bertambah sehingga memberikan bidang pantul yang terbatas.

\section{Transmission Electron Microscope (TEM)}

Karakterisasi nanopartikel kitosan dengan metode transmission electron microscope (TEM) dilakukan menggunakan instrumen Jeol TEM (JEM-1200EX) buatan Jepang. Karakterisasi dilakukan untuk melihat ukuran partikel nanopartikel kitosan. Ukuran partikel dapat dihitung dengan analisis gambar yang dihasilkan.

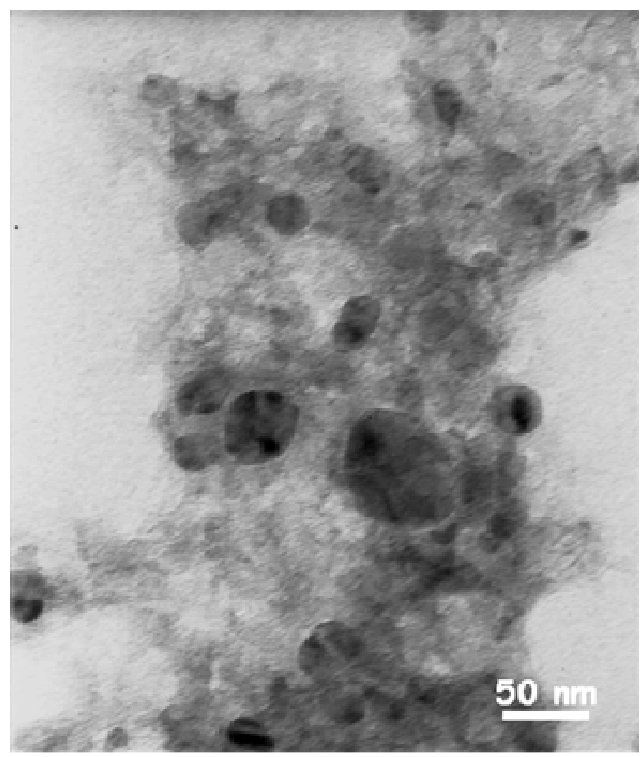

Gambar 4. Hasil TEM Nanopartikel Kitosan 
Hasil karakterisasi nanopartikel kitosan menggunakan TEM terlihat pada gambar 4 yang memberikan informasi kisaran ukuran partikel nanopartikel kitosan yaitu sebesar 23,08-61,54 nm. Hal ini menginformasikan bahwa nanopartikel kitosan yang digunakan pada penelitian ini memiliki skala ukuran nanometer.

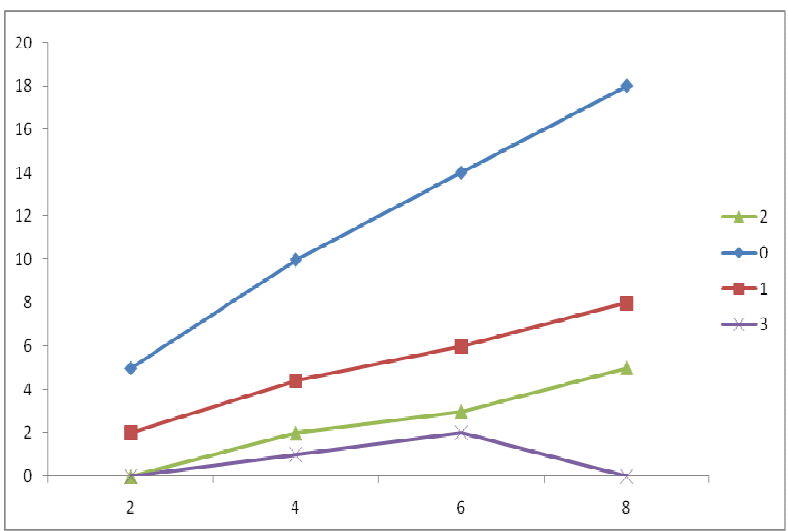

Gambar 4 Pengaruh Konsentrasi Nanopartikel Terhadap Susut Bobot

Pengaruh Konsentrasi Nanopartikel Kitosan B Terhadap Susut Bobot cabe Merah

Hasil pengamatan terhadap susut bobot cabe merah yang diberi lapisan nanopartikel kitosan ditunjukkan pada gambar 5. Pengamatan dilakukan setiap dua hari selama 8 hari. Hasil pengamatan menunjukkan bahwa makin besar konsentrasi nanopartikel kitosan makin kecil perubahan susut bobot. Menurut Jiang et al [14] bahwa buah yang diberi lapisan lilin dapat menghambat proses transpirasi, sehingga kerusakan jaringan buah dapat diperlambat. Berdasarkan hasil analisa sidik ragam konsentrasi nanopartikel kitosan $3 \%$ berpengaruh nyata dengan $\mathrm{p}<0,05$ terhadap susut bobot cabe merah

\section{Uji Vitamin C}

Hasil pengamatan kadar vitamin $\mathrm{C}$ pada buah cabe merah ditunjukkan pada gambar 5 .Pada penyimpanan 8 hari buah cabe merah yang tidak dilapis turun sebesar $62 \%$, sedangkan kadar vitamin $\mathrm{C}$ buah cabe merah yang dilapis dengan nanopartikel kitosan hanya turun sebesar $8 \%$. hal ini disebabkan pelapisan pada permukaan kulit buah dapat menghambat masuknya oksigen ke dalam jaringan buah, sehingga oksidasi vitamin $\mathrm{C}$ juga terhambat.

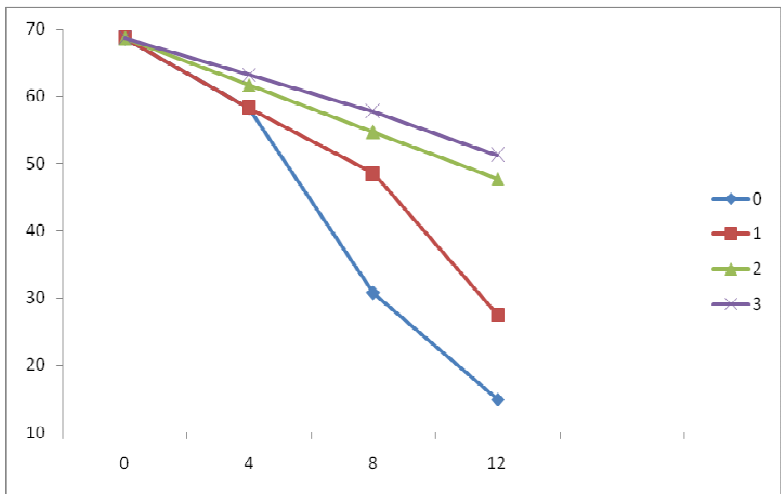

Gambar 6. Pengaruh waktu terhadap kandungan vitamin $\mathrm{C}$

\section{Kesimpulan}

Nanopartikel kitosan dibuat melalui reaksi ikatan silang antara gugus amina yang bermuatan positip dengan gugus poliphosphat yang bermuatan negatif. Data XRD dan TEM menunjukkan bahwa nanopartikel kitosan yang dihasilkan mempunyai ukuran partikel dalam skala nanomater.

Pelapisan buah cabe merah dengan larutan nanopartikel kitosan dapat memperpanjang umur simpan cabe merah yang semula 7 hari menjadi 16 hari dan dapat mempertahankan kualitas cabe merah segar karena dapat menghambat susut bobot,serta mempertahankan kandungan vitamin $\mathrm{C}$

\section{Penghargaan}

Penulis mengucapkan terima kasih kepada Lembaga Penelitian Universitas Negeri Jakarta yang telah membiayai penelitian ini dari dana DIPA UNJ tahun 2009 sesuai dengan surat perjanjian kerja nomor kontrak 21/SPK/LP-UNJ/DIPA-PNB/K2009 tanggal 31 Desember 2009.

\section{Daftar Pustaka}

1.Lin, W. C. 2005.. Quality of stored greenhouse sweet peppers influenced by storage temperatures and pre-harvest factors. Information and Technology for Sustainable Fruit and Vegetable Production (pp. 101-110). FRUTIC 05, 12-16, Montpellier France. 
2. Lerdthanangkul, S., \& Kroctha, J. M.1996. Edible coating effects on post harvest quality of green bell peppers. Journal of Food Science, 61 : 176-179.

3.Shimon Meir, Sonua Philosoph-Hadas, Susan Lurie and Yoram Fuchs. 1995. reduction of chilling injuri in stored avocadro, grapefruit and bell pepper by methyl jasmonate. Can.J.Bot $74: 870-874$.

4.Fallik.E.S; Grinberg.S; Alakali.S and S.Luire. 1996. The effectiveness of postharvest hot water dipping on the control of grey and black mould in sweet red pepper. Plant Pathology 45 : 644-649.

5. Maalekuu, K., Elkind, Y., Tuvia-Alkalai, S., Shalom, Y., \& Fallik, E. 2002. Quality evaluation of three sweet pepper cultivars after prolonged storage. Advances in Horticultural Science, 17 : 187-191.

6. Yage Xing, Xihong Li, Qinglian Xu, Juan Yun, Yaqing Lu, Yao Tang.2010 Effects of chitosan coating enriched with cinnamon oil on qualitative properties of sweet pepper (Capsicum annuum L.). Food Chemistry 124 (2011) 1443-1450.

7 Erol Ayranci and Sibel Tune. 2004. The effect of edible coatings on water and vitamin C loss of apricots (Armeniaca vulgaris Lam) and green peppers (Capsicum annuum).

8.Liu X.F; Guan Y.L; Yang D.Z; Li Z and yao K.D. 2001. Antibacterial action of chitosan and carboxymethylated chitosan. Journal of applied polymer science 79 : 1324-1335

9.Ying Chien Hung and Chih Yu Chen. 2008. Antibacterial characteristic and activity of acid soluble chitosan. Bioresource technology 99 : 2806-2814.

10.Purnama Darmadji and Masatoshiu Izumimoto. 1994. Effect of chitosan in meta preservation. Meat Science 38 : 243-254.

11. Meng, X., Li, B., Liu, J., \& Tian, S. (2008). Physiological responses and quality tributes of table grape fruit to chitosan preharvest spray and postharvest coating during storage. Food Chemistry, 106, 501-508.

12. Ghaouth, A. E., Arul, J., Ponnampalam, R., \& Boulet, M. 1991. Use of chitosan coating to reduce weight loss and maintain quality of cucumber and bell pepper fruits. Journal of Food Processing and Preservation, 15: 359-368.

13.Po-Jung Chien; Fuu Sheu and Hung-Ren Lin.2005. Coating citrus fruit with low molecular weight chitosan increase postharvest quality and shelf life. Food chemistry 77 : 190-201

14.Jiang Y.M; Jianrong Li and Weibo Jiang. 2005. Effects of chitosan coating and shelf life of cold storage litchi fruit at ambient temperature . Food science and technology 38 : 757 761.

15,Zhong Qiuping and Xia Wenshui. 2006. Effect of 1-merhylcyclopropene and chitosan coating treatments on storage life and maintenance of Indian jujube fruit. Food science and technology 39 : 266-278

16. Jiang Y.M and Y.B. Li .2001. Effects of chitosan on shelf life and quality of fresh cut Chinese water chestnut. Lebensmittel-Wissenchaft Und-technologoi 36 : 359

17,Jiang Y.M and Y.B.Lie. 2002. Effects of chitosan coating on storage life and quality of longan fruit. Food Chemistry 73 : 139-143.

18.Wu Yi. 1999. Moisture loss and lipid oxidation for precooked ground beef patties stored in protein and polysaccharides edible/biodegradable films and coatings. Journal of food science $38: 45-55$

19.Rechelle L.Beverlya; Marlene E.Janes; Witoon Prinyawiwatkula; Hong.KNio .2008. Edible 
chitosan films on readey to eat roast beef for the control of Listeria monocytogenes.Food microbiology 25 : $534-537$

20.Lifeng Qi; Zirong Xu; Xia Jiang; Caihong $\mathrm{Hu}$ and Xiangfei Zou. 2004. Preparation and antibacterial activity of chitosan nanoparticles. Carbohydrate Research 339: 2693-2700. 